\title{
Effect of increasing amounts of milk replacer powder added to whole milk on postweaning performance, reproduction, glucose metabolism, and mammary fat pad in dairy heifers
}

\author{
C. F. A. Lage, ${ }^{*}$ R. A. Azevedo, ${ }^{*}$ F. S. Machado, $†$ M. M. Campos, $†$ L. G. R. Pereira, $\dagger$ T. R. Tomich, $\dagger$ \\ B. C. Carvalho,† B. R. C. Alves,† G. B. Santos, ‡ F. Z. Brandão, $\ddagger$ and S. G. Coelho*1 \\ *Department of Animal Science, School of Veterinary Medicine, Federal University of Minas Gerais, Minas Gerais, 30161-970, Brazil \\ †Brazilian Agricultural Research Corporation (Empresa Brasileira de Pesquisa Agropecuária, EMBRAPA), \\ National Center for Research on Dairy Cattle, Minas Gerais, 36038-330, Brazil \\ $\ddagger$ Department of Animal Science, School of Veterinary Medicine, Fluminense Federal University, Rio de Janeiro, 24220-900, Brazil
}

\section{ABSTRACT}

The aim of this study was to evaluate the effects of increasing the total solids (TS) content of liquid feed, by adding increasing amounts of milk replacer powder to whole milk, on age at puberty and postweaning performance, glucose metabolism, and mammary fat pad of dairy heifers. Crossbreed Holstein $\times$ Gyr heifers $(\mathrm{n}=58)$ were distributed into 4 different treatments during the preweaning period. Treatments consisted of liquid feeds with TS content of 12.5 (actual TS $=13.5$ $\pm 0.53 \% ; \mathrm{n}=15$ ), 15.0 (actual $\mathrm{TS}=16.1 \pm 0.03 \%$; $\mathrm{n}=15), 17.5$ (actual TS $=18.2 \pm 0.14 \% ; \mathrm{n}=13$ ), or $20.0 \%$ (actual TS $=20.4 \pm 0.24 \%$; $\mathrm{n}=15$ ), which were provided up to $59 \mathrm{~d}$ old. From 60 to $89 \mathrm{~d}$ old, the animals received the same starter offered during the preweaning period in addition to corn silage ad libitum starting at $70 \mathrm{~d}$ old. From 90 to $104 \mathrm{~d}$ old, the animals were adapted to a total mixed ration. At $105 \mathrm{~d}$ old, the animals were distributed in 4 paddocks equipped with electronic feed and water bins and were fed the same total mixed ration ad libitum. A period of adaptation to the electronic feed bins occurred from 105 to $119 \mathrm{~d}$ old. Feed and water intake and body weight and body frame development were assessed until puberty. Mammary gland evaluations were performed monthly by ultrasonography from $120 \mathrm{~d}$ of age until puberty onset. Puberty onset was determined as plasma progesterone concentration greater than $1 \mathrm{ng} / \mathrm{mL}$ in 2 consecutive samples collected $7 \mathrm{~d}$ apart. The date of puberty onset was recorded as the collection day of the first of these samples. A glucose tolerance test was performed at 280 $\mathrm{d}$ of age. The increased TS content of the liquid feed fed during the preweaning period did not affect dry

\footnotetext{
Received November 22, 2016.

Accepted July 22, 2017.

${ }^{1}$ Corresponding author: sandragesteiracoelho@gmail.com
}

matter intake, performance, age at puberty, glucose metabolism, or mammary gland fat pad at later stages of rearing process. Conversely, hip width and heart girth increased linearly up to 150 and $240 \mathrm{~d}$ of age, respectively, as a result of the increased TS concentration of the liquid feed during the preweaning period.

Key words: later stages of rearing process, mammary gland, puberty, ultrasound

\section{INTRODUCTION}

Restricted liquid feeding strategies, especially during the first month of life, have been challenged by recent research in dairy calves. New strategies for increasing nutrient intake via liquid feed have been proposed to improve the future productivity of cattle. The effects of those feeding strategies have been evaluated in relation to dairy heifers' performance (Omidi-Mirzaei et al., 2015; Azevedo et al., 2016a,b; Overvest et al., 2016), health (Obeidat et al., 2013; Ballou et al., 2015), behavior (Miller-Cushon et al., 2013; Guindon et al., 2015; Jensen et al., 2015), insulin sensitivity (Bach et al., 2013; Yunta et al., 2015, MacPherson et al., 2016), and mammary gland development (Esselburn et al., 2015; Geiger et al., 2016a,b). However, investigations of the long-term effects of preweaning calf management strategies associated with greater growth rates on reproductive performance and mammary gland development have yielded variable results (Raeth-Knight et al., 2009; Yunta et al., 2015; Gelsinger et al., 2016).

Feeding large volumes of liquid feed twice daily during the preweaning period induces insulin sensitivity during the preweaning period (Bach et al., 2013; Yunta et al., 2015) and may have longstanding effects on digestion and metabolism (MacPherson et al., 2016). The transposing effects on insulin sensitivity due to intensive feeding during the preweaning period, however, requires further clarification. 
In addition to effects on overall metabolism, greater DMI during early life may affect mammary gland development, especially regarding fat deposition (Brown et al., 2005). The evaluation of mammary gland development (parenchyma and fat pad) of heifers that received or did not receive intensive nutrition is usually done after slaughter (Capuco et al., 1995; Brown et al., 2005; Geiger et al. 2016a,b). Thus, the understanding of early gland mammary development and its long-term consequences is still limited. Advances in ultrasound (US) technology have allowed the harvest of quantitative information in vivo, which had not been formerly assessed (Esselburn et al., 2015). Examination of mammary tissue by US has been previously reported and validated in dairy heifers (Nishimura et al., 2011; Albino et al., 2015, 2017; Esselburn et al., 2015; Weller et al., 2016).

The aim of our study was to evaluate the effects of increasing the TS content of liquid feed, by adding increasing amounts of milk replacer powder to whole milk, on performance, age at puberty, glucose metabolism, and mammary fat pad of dairy heifers during the postweaning period. Our hypothesis was that an increased liquid feed TS content during the preweaning period would anticipate puberty onset, reduce insulin sensitivity, and cause alterations in the mammary gland fat pad when compared with liquid feed with lower TS content.

\section{MATERIALS AND METHODS}

The study was approved by the Ethics Committee of Embrapa Dairy Cattle, Brazil (protocol number 21/2014). The experiment was conducted at the Embrapa Dairy Cattle Experimental Farm, located in Coronel Pacheco, Minas Gerais, Brazil.

\section{Animals, Housing, Management, and Treatments}

Holstein $\times$ Gyr crossbred heifers $(\mathrm{n}=58)$ were enrolled, and their genetic composition was at least $5 / 8$ Holstein and a maximum of $3 / 8$ Gyr. The same heifers were previously studied by Azevedo et al. (2016a) from 5 to $89 \mathrm{~d}$ of age regarding the effect of increasing liquid feed TS concentration by adding milk replacer powder (MRP) to whole milk on performance, intake, and fecal score. Detailed descriptions of facilities, initial care, and nutritional composition of diets provided during the preweaning (5-59 d of age) and early postweaning (60-89 d of age) periods can be found in Azevedo et al. (2016a).

The heifers were randomly assigned to 1 of 4 treatments at birth. Preweaning treatments consisted of increasing amounts of MRP (Sprayfo Violet SSP, Sloten
BV, Deventer, the Netherlands) added to whole milk $(12.6 \pm 0.7 \%$ TS, mean $\pm \mathrm{SD}$; Table 1$)$ to adjust the TS content to expected concentrations of 12.5 (actual $\mathrm{TS}=13.5 \pm 0.53 \% ; \mathrm{n}=15), 15.0$ (actual $\mathrm{TS}=16.1$ $\pm 0.03 \% ; \mathrm{n}=15$ ), 17.5 (actual $\mathrm{TS}=18.2 \pm 0.14 \%$; $\mathrm{n}=13$ ), and $20.0 \%$ (actual TS $=20.4 \pm 0.24 \%$; $\mathrm{n}=$ 15). Two heifers (treatment $17.5 \% \mathrm{TS}$ ) were withdrawn from the study; one in the last week of the postweaning period due to an accident and another during the adaptation to a diet (between 90 and $104 \mathrm{~d}$ of age) as a result of death by anaplasmosis. The MRP was added to the whole milk immediately before being supplied to the heifers. The total volume of liquid feed $(6 \mathrm{~L} / \mathrm{d})$ was divided into 2 equal meals (0800 and $1600 \mathrm{~h})$ and provided to heifers in buckets from 5 to $55 \mathrm{~d}$ of age. At $56 \mathrm{~d}$ of age, the total liquid feed volume was reduced by half $(3 \mathrm{~L} / \mathrm{d}$ provided at $0800 \mathrm{~h}$ only). The heifers were weaned at $60 \mathrm{~d}$ of age. Starter (Soylac Rumen 20\% Flocculated, Total Alimentos, Três Corações, Brazil) and water were offered ad libitum during the pre- and postweaning period. At $70 \mathrm{~d}$ of age, corn silage was included in the diet in a separate bucket and was offered ad libitum. Between 90 and 104 d of age, heifers were regrouped in pens $\left(280 \mathrm{~m}^{2} /\right.$ pen; 15 animals/pen $)$ for socialization and adaptation to a diet composed of fixed amount ( $2 \mathrm{~kg}$ /animal per day) of concentrate (96\% soybean meal, $4 \%$ mineral and vitamin premix, DM basis) and ad libitum corn silage. Concentrate was placed on top of silage from 90 to $96 \mathrm{~d}$ of age and handmixed with silage during the next week. Month of birth and treatment group were randomized for each pen.

At $105 \mathrm{~d}$ of age, the groups of heifers were moved to pens $\left(450 \mathrm{~m}^{2}\right)$ according to the previous groups and were adapted until $d$ 119. The pens had no grass; 4 pens were used and the final stoking of each was 15 animals in pen 1, 14 animals in pen 2, 14 animals in pen 3 , and 15 animals in pen 4 . The heifers had ad libitum access to feed, which was provided using the electronic feed bins (AF -1000 Junior; Intergado Ltd., Minas Gerais, Brazil) per each pen. The TMR was offered twice daily (0800 and $1500 \mathrm{~h}$ ) and consisted of $2 \mathrm{~kg}$ of concentrate per animal mixed with ad libitum corn silage using a mixer wagon (Calan Data Ranger, American Calan Inc., Norwood, NH). Orts were daily removed from the feed bins before morning feeding and, given the fixed amount of concentrate, the amount of corn silage was adjusted daily to target $10 \%$ orts. The silage proportions in total diets (DM basis) ranged proportionately from 0.50 to 0.78 , with a mean value of 0.71 . Water was offered ad libitum using 1 electronic water bin (WD-1000 Junior, Intergado Ltd.) at each pen. Animals were observed daily for signs of injury or disease and were treated according to routine farm management practices. 
Table 1. Nutrient composition of concentrate, corn silage, and diet offered for heifers from $120 \mathrm{~d}$ of age to age at puberty

\begin{tabular}{lcrrr}
\hline & & & \multicolumn{2}{c}{ Diet $^{2}$} \\
\cline { 3 - 5 } $\begin{array}{l}\text { Nutrient composition } \\
\text { (DM basis, \%) }\end{array}$ & Corn silage & Concentrate $^{1}$ & Mean & SD \\
\hline DM & 29.70 & 90.86 & 47.16 & 4.52 \\
CP & 7.96 & 47.52 & 19.25 & 2.92 \\
Ether extract & 3.36 & 2.33 & 3.06 & 0.08 \\
Ash & 5.35 & 7.28 & 5.90 & 0.14 \\
NDF & 52.00 & 11.82 & 40.51 & 2.97 \\
ADF & 27.54 & 6.55 & 21.54 & 1.55 \\
TDN & 70.06 & 84.14 & 74.06 & 1.07 \\
Phosphorus & 0.17 & 0.74 & 0.33 & 0.04 \\
Magnesium & 0.19 & 0.44 & 0.26 & 0.02 \\
\hline
\end{tabular}

${ }^{1}$ Concentrate containing (DM basis) $96 \%$ soybean meal and $4 \%$ mineral and vitamin premix, composed of calcium $(192 \mathrm{~g} / \mathrm{kg})$, cobalt $(90 \mathrm{mg} / \mathrm{kg})$, copper $(1,500 \mathrm{mg} / \mathrm{kg})$, sulfur $(25 \mathrm{~g} / \mathrm{kg})$, fluorine $(897 \mathrm{mg} / \mathrm{kg})$, phosphorus $(80 \mathrm{~g} / \mathrm{kg})$, iodine $(90 \mathrm{mg} / \mathrm{kg})$, magnesium $(20 \mathrm{~g} / \mathrm{kg})$, manganese $(3,000 \mathrm{mg} / \mathrm{kg})$, selenium $(25 \mathrm{mg} / \mathrm{kg})$, sodium $(103 \mathrm{~g} / \mathrm{kg})$, vitamin A $(160,000 \mathrm{IU} / \mathrm{kg})$, vitamin $\mathrm{D}_{3}(40,000 \mathrm{IU} / \mathrm{kg})$, vitamin $\mathrm{E}(1,000 \mathrm{IU} / \mathrm{kg})$, and zinc $(5,000$ $\mathrm{mg} / \mathrm{kg})$.

${ }^{2}$ Mean (SD) composition of diet containing different proportions of corn silage and concentrate over the study (given the amount of concentrate offered was fixed at $2 \mathrm{~kg}$ per animal, as fed, and the amount of silage was adjusted daily to target $10 \%$ orts).

\section{Intake, Performance, and Growth}

Performance, body frame development, and individual feed and water intake were monitored from $120 \mathrm{~d}$ of age until puberty onset. All heifers received an ear tag with a passive transponder (FDX-ISO 11784/11785; Allflex, Joinville, SC, Brazil), which allowed recording of individual daily feed and water intake by the Intergado electronic system, previously validated by Chizzotti et al. (2015). Feed efficiency was calculated using the ratio between ADG and total DMI (Khan et al., 2007).

Heifers were weighed once per week before the morning feeding using an electronic scale (Toledo MGR-2000, São Bernardo, Brazil). Regression models were created to calculate the weight of the animals at the evaluated ages starting at $120 \mathrm{~d}$ of age. The ADG was calculated as the difference in weight between the evaluated periods divided by the number of days within the interval. The morphometric measurements were performed every $14 \mathrm{~d}$, in 2 replications, in a flat location, allowing the animals to remain with their limbs well set. The withers height (distance from the withers to the ground) and hip height (distance from iliosacral tuberosity to the ground) were evaluated using a hipometer (Walmur, Porto Alegre, Brazil). The heart girth (measured immediately caudally to the front limbs) and the hip width (distance between the 2 iliac tuberosities) were evaluated with a measuring tape (Bovitec, São Paulo, Brazil).

\section{Reproductive Performance}

To determine age at puberty onset, blood samples were collected weekly from each heifer after reaching
$200 \mathrm{~kg}$ of BW. Blood was collected in tubes containing EDTA K2/K3 (Labor Import, Osasco, Brazil). Plasma was immediately separated by centrifugation at 1,500 $\times g$ for $15 \mathrm{~min}$ at room temperature $\left(22-25^{\circ} \mathrm{C}\right)$ and stored at $-20^{\circ} \mathrm{C}$ until further analysis for progesterone concentration. Progesterone analysis was performed using solid-phase radioimmunoassay kits (ImmuChem Coated Tube, ICN Pharmaceuticals Inc., Costa Mesa, $\mathrm{CA})$. Intra- and interassay coefficient of variation and standard deviation were $12 \pm 0.16$ and $11 \pm 0.15 \%$, respectively. Puberty was confirmed when plasma progesterone concentrations were greater than $1 \mathrm{ng} / \mathrm{mL}$ in 2 consecutive samples (Davis Rincker et al., 2011). Age at puberty onset was recorded as the age at the collection day of the first of these 2 samples. All animals reached puberty. Body weight at puberty was estimated by interpolation from 2 weekly weights.

\section{Mammary Gland Ultrasound}

The development of the mammary gland was evaluated monthly from $120 \mathrm{~d}$ of age until puberty onset. All ultrasonography images were obtained by the same person using a B-mode US equipped with a micro-convex transducer of $6 \mathrm{MHz}$ (DP 2200, Mindray, Shenzhen, China). The animals remained standing and contained (Coimma Head Gate, Dracena, Sao Paulo, Brazil) during the evaluation of the mammary glands (front and rear quarters, both sides). The probe was placed in a standardized position at $45^{\circ}$ in relation to the teat position, always in caudal-cranial orientation (Nishimura et al., 2011). To improve image visualization, the scanned area was wetted with $70 \%$ alcohol and US lubricant (Carbogel ULT, Sao Paulo, Brazil). 
One image was captured for each mammary gland of each animal. The images were saved in BMP format and transferred to the ImageJ software (National Institutes of Health; https://imagej.nih.gov/ij/) for further analysis. Four $20-\mathrm{mm}^{2}$ squares were placed randomly in each image, avoiding the area above the teat cistern by approximately $4 \mathrm{~mm}$ (Albino et al., 2015). The average number of pixels of each square was used to calculate the average pixels per image. The average pixels of the front and rear mammary glands were obtained and grouped per animal and period. In 8-bit images, each pixel is numerically represented on a scale of 256,000 shades of gray $(0=$ black; $256,000=$ white $)$ according to their brightness (Ferreira and Rasband, 2011). The amplitude or brightness of pixels (0-255,000 scale) can be defined in terms of echogenicity; that is, structures with high capacity to reflect sound waves are hyperechoic and have more pixels (e.g., adipose tissue) whereas structures with limited capacity to reflect sound waves are hypoechoic and have fewer pixels (e.g., mammary parenchyma; Albino et al., 2015).

\section{Glucose Tolerance Test}

Heifers randomly selected from each treatment group $(13.5 \%$ TS, $\mathrm{n}=6 ; 16.1 \% \mathrm{TS}, \mathrm{n}=6 ; 18.2 \% \mathrm{TS}, \mathrm{n}=7$; and $20.4 \% \mathrm{TS}, \mathrm{n}=7$ ) were submitted to an intravenous glucose tolerance test (GTT) at $280 \pm 5 \mathrm{~d}$ of age. To maintain basal plasma glucose levels before the infusion, solid feed was removed $5 \mathrm{~h}$ before the GTT start time. An indwelling catheter (Abbocath-T 16 gauge $\times$ $140 \mathrm{~mm}$; Hospira Inc., Lake Forest, IL) was placed in the left jugular vein. The catheter was used to infuse glucose (50\% dextrose solution; Glucose 50\%, Isofarma, Eusébio, Ceará, Brazil; $0.3 \mathrm{~g} / \mathrm{kg}$ of BW administered over $1 \mathrm{~min}$ ) and to collect blood samples. This dose was calculated based on previous studies with heifers (Sumner et al., 2007) and dairy cows (Marett et al., 2015); therefore, a renal dose threshold was not evaluated in the present study. Blood samples were collected at $-20,-10,-1,0,5,10,20,30,40,60,80,100$, and 240 min relative to the glucose infusion into tubes without anticoagulant (for insulin dosage) or with sodium fluoride and EDTA $K_{2} /$ EDTA $K_{3}$ (for glucose dosage; Vacutainer, Becton, Dickinson and Company, Franklin Lakes, NJ). The heifers were restricted from access to TMR and water at all times during sampling. Body condition score (ranked on a scale of 1 to 5; Edmonson et al., 1989) was determined at the day of the GTT.

\section{Blood Samples}

To assess circulating insulin and glucose concentrations, blood samples were collected into tubes without anticoagulant (for insulin) or with sodium fluoride (for glucose; Vacutainer; Becton, Dickinson and Company). Tubes were placed in crushed ice until centrifugation at $1,800 \times g$ for $10 \mathrm{~min}$ at room temperature $\left(22-25^{\circ} \mathrm{C}\right)$. Plasma or serum aliquots were stored at $-20^{\circ} \mathrm{C}$ until analysis. Plasma glucose was measured on a microplate Spectrophotometer EON (Biotek Instruments Inc., Winooski, VT) using an enzymatic colorimetric method (Kovalent do Brasil Ltda., Rio de Janeiro, Brazil). Intra- and interassay coefficients of variation were $\leq 3 \%$. Insulin was analyzed using a bovine ELISA kit (Mercodia, Uppsala, Sweden); intra- and interassay coefficients of variation were $\leq 7.0$ and $8.2 \%$, respectively.

\section{Nutritional Composition Analysis}

Samples of TMR, silage, and concentrate were collected thrice per week, pooled into a weekly sample, and stored at $-20^{\circ} \mathrm{C}$ until analysis. Feed samples (TMR and corn silage) were dried in a forced-ventilation oven at $55^{\circ} \mathrm{C}$ for $72 \mathrm{~h}$ and were ground to $1-\mathrm{mm}$ particle size in a Wiley Mill (model 3, Arthur H. Thomas Co., Philadelphia, PA). All samples were analyzed for DM, CP, ether extract, ash, calcium, and phosphorus according to AOAC International (1995). Both NDF and ADF were determined according to the methods of Van Soest et al. (1991; Table 1). The concentration of TDN in diets was calculated as digestible $\mathrm{CP}+$ digestible NFC + digestible $\mathrm{NDF}+$ (digestible fatty acids $\times 2.25$ ).

\section{Statistical Analysis}

Data were analyzed using SAS 9.0 (SAS Institute Inc., Cary, NC). Regression models were generated for intake, performance, and growth data to compare treatments among periods of 120,150,180, 210, and $240 \mathrm{~d}$ of age. Blood samples collected at $-20,-10$, and 0 min before glucose infusion were used to determine baseline concentrations of glucose and insulin. The maximum increase in glucose and insulin were defined as the mean maximum concentrations achieved by each group after glucose infusion, and the insulin-to-glucose ratio at 10 min postinfusion was calculated by dividing the insulin concentration by the glucose concentration at that time. The positive incremental area under the curve for glucose and insulin was evaluated using the trapezoid rule for values above baseline and was calculated over $540 \mathrm{~min}$ for the postprandial responses and over $60 \mathrm{~min}$ for the GTT. The clearance rates of glucose and insulin during the GTT were calculated using the method established by Pires et al. (2007):

$$
\begin{gathered}
\text { Clearance rate }(\% / \mathrm{min})=\{[\ln (\mathrm{ta})-\ln (\mathrm{tb})] / \\
(\mathrm{ta}-\mathrm{tb})\} \times 100
\end{gathered}
$$


where ta and tb are the concentrations of insulin or glucose at times ta or tb, respectively. Insulin sensitivity was estimated using a simplified model described by Christoffersen et al. (2009).

Postweaning (120-240 d of age) feed and water intake, performance, feed efficiency, and body frame development and GTT were analyzed using PROC MIXED of SAS REPEATED statement, including heifer as the random term and treatment, day of age, or hour of sampling (GTT) and their interaction as fixed variables. Variables regarding mammary gland development were analyzed using PROC MIXED of SAS REPEATED statement, including heifer as the random term and treatment, day of age, mammary gland (front and rear), and their interaction as fixed variables. For postweaning and mammary gland variables, orthogonal polynomial contrasts to estimate linear and quadratic effects of increasing liquid feed TS concentration during the preweaning period were used only when the effect of the treatment or the interaction between treatment and period were significant. The differences in the mean of pixels in the mammary gland images (front and rear, both sides) were analyzed using Tukey's adjustment for $P$-values. Variables with a single measurement during the study (such as BW at puberty and glucose baseline) were analyzed by using the GLM procedure with orthogonal polynomial contrasts to estimate the linear and quadratic effects of increased TS concentration in the liquid feed. Least squares means are reported for each treatment. The variables age, BW at $280 \mathrm{~d}$ of age, and BCS were considered as covariates for the glucose metabolism analyses. Significance was declared at $P \leq$ 0.05 .

\section{RESULTS AND DISCUSSION}

According to Azevedo et al. (2016a), increasing TS in whole milk by the addition of milk replacer powder up to $20.4 \%$ TS is an option for increasing pre- and postweaning (5-89 d of age) performance and body frame development of dairy heifers, with no effects on solid feed intake, fecal score, or days with diarrhea.

\section{Intake, Performance, and Growth Measurements}

Total DM and water intake up to $240 \mathrm{~d}$ of age were similar among treatments and increased with age $(P$ $\leq$ 0.01; Table 2). Azevedo et al. (2016b) demonstrated that male calves receiving liquid feed with the same levels of TS evaluated in the present study did not present differences in ruminal development, indicating similarity between the digestive and absorptive capacities of the animals. These results suggest that the provision of liquid feed with greater TS concentration during the preweaning period did not affect rumen development, therefore not compromising postweaning feed intake. The same was observed when calves receiving larger volumes of liquid feed were weaned at 8 versus 6 wk of age (Eckert et al., 2015) or when gradual weaning was adopted (Khan et al., 2007; Sweeney et al., 2010; Silper et al., 2014).

Body weight, ADG, feed efficiency, as well as withers height and hip height up to $240 \mathrm{~d}$ of age were similar among treatments (Table 2). We noted interactions $(P$ $\leq$ 0.05; Table 2) among treatments and ages for heart girth and hip width up to $240 \mathrm{~d}$ of age. Up to $180 \mathrm{~d}$ of age a linear increase $(P \leq 0.05)$ occurred in the heart

Table 2. Postweaning (120-240 d of age) feed and water intake, performance, feed efficiency, and body frame development of dairy heifers fed different TS contents in whole milk during the preweaning period (5-59 d of age)



${ }^{1} \mathrm{~T}=$ treatment effect; $\mathrm{DOA}=$ day of age effect; $\mathrm{T} \times \mathrm{DOA}=$ treatment by day of age interaction. 
girth of heifers fed liquid feed with greater TS concentrations during the preweaning period, with no effect after $210 \mathrm{~d}$ of age (Figure 1a). A linear increase $(P \leq$ 0.05 ) of hip height measurements was observed at 120 $\mathrm{d}$ of age according to the increasing liquid feed TS concentrations; however, no effect was observed after $150 \mathrm{~d}$ of age (Figure 1b). Kiezebrink et al. (2015) also did not observe BW differences after $354 \mathrm{~d}$ of age in animals that received 4 or $8 \mathrm{~L} / \mathrm{d}$ of liquid feed until $56 \mathrm{~d}$ of age, and reported that differences in hip height were not observed after 112 d of age. Yunta et al. (2015) reported that at $300 \mathrm{~d}$ of age no difference in BW could be found between heifers fed 6 or $8 \mathrm{~L} / \mathrm{d}$ of liquid feed during the preweaning period.

\section{Body Weight and Development at Puberty and Reproductive Parameters}

Body weight, measurements of body development, and age at puberty onset were similar among treatments
(Table 3). According to Schillo et al. (1992), puberty onset occurs when animals reach 40 to $50 \%$ of adult BW. The differences in preweaning ADG (Azevedo et al., 2016a) and the absence of differences in postweaning ADG (Table 2) do not explain the similar age at puberty onset among treatments, suggesting no carryover effect of the preweaning nutritional plan with greatest TS content on age at puberty onset. The current study is the first to investigate the effects of increased TS in the liquid feed during the preweaning period on later stages of rearing process and we did not observe reproductive changes. Further research in this area is needed to better determine the effect of enhanced TS in liquid feeding of calves on subsequent first-lactation performance. Similar results were observed by Terré et al. (2009) and Yunta et al. (2015), who did not observe differences in age at first conception and age at first calving in animals fed 3 or $7 \mathrm{~L} / \mathrm{d}$ and 4.6 or $8.0 \mathrm{~L} / \mathrm{d}$ of liquid feed, respectively. Shamay et al. (2005), however, showed that heifers receiving milk ad libitum reached

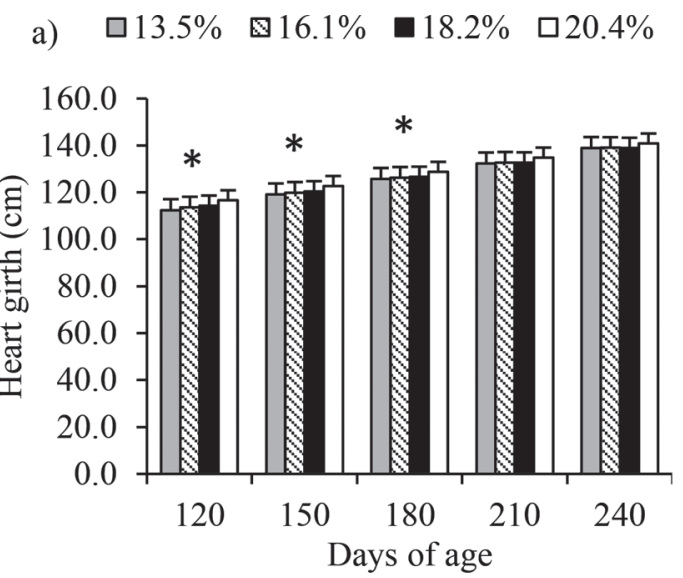

b) $\quad \square 13.5 \% \quad \mathrm{Q} 16.1 \% \quad \square 18.2 \% \quad \square 20.4 \%$

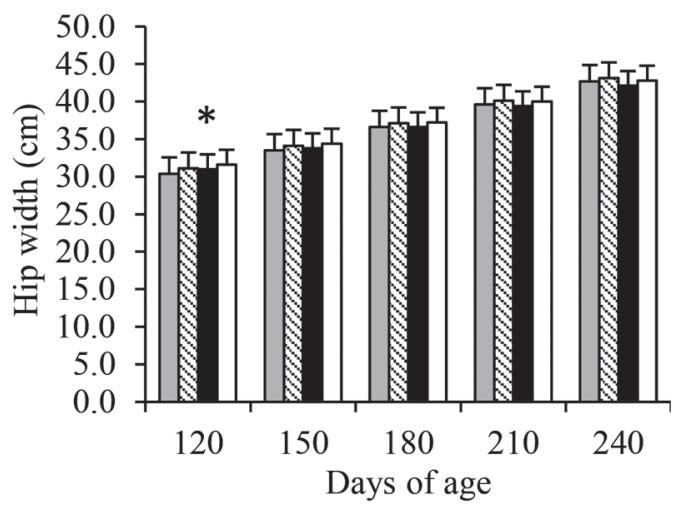

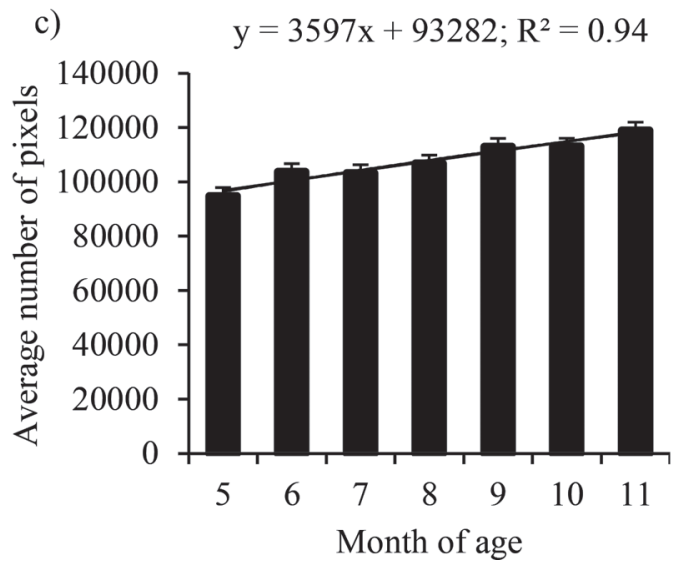

Figure 1. (a) Heart girth (cm) and (b) hip width $(\mathrm{cm})$ during the postweaning period (120-240 d of age) and (c) average number of pixels of the front and rear mammary glands pooled for each animal from 5 to 11 mo of age in dairy heifers fed different TS contents (13.5, 16.1, 18.2, and $20.4 \%)$ in liquid feed. An asterisk $\left(^{*}\right)$ represents the linear effect of treatments $(P \leq 0.05)$. Error bars represent SE. 
Table 3. Body weight, body frame development, and age at puberty of dairy heifers fed different TS contents in whole milk during the preweaning period ( $5-59 \mathrm{~d}$ of age)

\begin{tabular}{|c|c|c|c|c|c|c|c|}
\hline \multirow[b]{2}{*}{ Item } & \multicolumn{4}{|c|}{ Treatment (\% TS in whole milk) } & \multirow[b]{2}{*}{ SEM } & \multicolumn{2}{|c|}{ Contrast, $P$-value } \\
\hline & $\begin{array}{c}13.5 \\
(\mathrm{n}=15)\end{array}$ & $\begin{array}{c}16.1 \\
(\mathrm{n}=15)\end{array}$ & $\begin{array}{c}18.2 \\
(\mathrm{n}=13)\end{array}$ & $\begin{array}{c}20.4 \\
(\mathrm{n}=15)\end{array}$ & & Linear & Quadratic \\
\hline Withers height & 119 & 121 & 121 & 122 & 0.51 & 0.11 & 0.85 \\
\hline Heart girth & 151 & 152 & 153 & 154 & 0.76 & 0.10 & 0.79 \\
\hline Age at puberty (d) & 292 & 308 & 308 & 315 & 4.73 & 0.10 & 0.60 \\
\hline
\end{tabular}

puberty $23 \mathrm{~d}$ earlier than heifers that received milk replacer (450 g of DM/d). It is important to emphasize that heifers studied herein reached puberty on average at 10 mo of age, earlier than previously reported by Facó et al. (2005) for crossbred Holstein $\times$ Gyr heifers.

\section{Glucose Metabolism}

In contrast to our hypothesis, the provision of greater amounts of TS twice daily during the preweaning period did not alter insulin sensitivity postweaning (Table 4). Similar results were observed by MacPherson et al. (2016), who did not observe alterations in GTT kinetics between treatments characterized by feeding milk replacer at high $(8 \mathrm{~L} / \mathrm{d})$ or low $(4 \mathrm{~L} / \mathrm{d})$ levels twice a day to heifers that were submitted to GTT pre- and postweaning ( 4,7 , and $10 \mathrm{wk}$ of age). In the present study, however, GTT was performed only in the postweaning period. If insulin sensitivity occurred at some stage of the animal's life, this condition disappeared before 280 d of age, when GTT was performed. Yunta et al. (2015) showed that preweaning glycemia differences observed between groups disappeared at $84 \mathrm{~d}$ of age and reversed at $300 \mathrm{~d}$ of age. According to those authors, heifers receiving $8 \mathrm{~L} / \mathrm{d}$ required lower amounts of insulin to control blood glucose than heifers who received 4 or $6 \mathrm{~L} / \mathrm{d}$ of liquid diet during the preweaning period. These results indicate that a condition of insulin sensitivity may occur in animals with high nutrition levels during the preweaning period, but this may not be a long-term occurrence. Studies of glucose metabolism in heifers during pre- and postweaning periods should be performed to better understand the effect of diets on glucose metabolism, as the mechanisms of insulin secretion by the pancreas in response to concentrations of glucose are not fully developed until several months after birth (Grütter and Blum, 1991). After 2 mo of age, specific changes occur in the liver and rumen gene expression to sustain the use of energy derived from ruminal fermentation (Grütter and Blum, 1991;

Table 4. The effect of different TS contents in whole milk fed during the preweaning period (5-59 d of age) on glucose and insulin responses to an intravenous glucose tolerance test in dairy heifers with $280 \mathrm{~d}$ of age

\begin{tabular}{|c|c|c|c|c|c|c|c|}
\hline \multirow[b]{2}{*}{ Item } & \multicolumn{4}{|c|}{ Treatment (\% TS in whole milk) } & \multirow[b]{2}{*}{ SEM } & \multicolumn{2}{|c|}{ Contrast, $P$-value } \\
\hline & $\begin{array}{c}13.5 \\
(\mathrm{n}=6)\end{array}$ & $\begin{array}{c}16.1 \\
(\mathrm{n}=6)\end{array}$ & $\begin{array}{c}18.2 \\
(\mathrm{n}=7)\end{array}$ & $\begin{array}{c}20.4 \\
(\mathrm{n}=7)\end{array}$ & & Linear & Quadratic \\
\hline Insulin baseline $(\mu \mathrm{U} / \mathrm{mL})$ & 2.73 & 2.36 & 3.09 & 2.56 & 0.28 & 0.93 & 0.90 \\
\hline Glucose $\mathrm{AUC}^{1}(\mathrm{mg} / \mathrm{dL} \times 60 \mathrm{~min})$ & $3,260.80$ & $2,603.87$ & $3,425.41$ & $3,882.17$ & 176.27 & 0.08 & 0.09 \\
\hline Insulin $\mathrm{AUC}^{1}(\mu \mathrm{U} / \mathrm{mL} \times 60 \mathrm{~min})$ & $1,109.26$ & 505.22 & $1,060.57$ & 567.35 & 137.81 & 0.37 & 0.84 \\
\hline Clearance rate of glucose $(\% / \mathrm{min})$ & 0.45 & 0.39 & 0.45 & 0.38 & 0.02 & 0.50 & 0.98 \\
\hline Clearance rate of insulin ( $\% / \min )$ & 1.26 & 0.95 & 1.25 & 1.49 & 0.10 & 0.27 & 0.21 \\
\hline Insulin to glucose $(\mu \mathrm{U} / \mathrm{mg})(10 \mathrm{~min})$ & 18.49 & 13.75 & 21.13 & 12.73 & 2.40 & 0.63 & 0.70 \\
\hline $\begin{array}{l}\text { Insulin sensitivity }^{2}(\mathrm{~mL} / \mathrm{min} \times \mu \mathrm{U} / \mathrm{mL} \\
\text { per kilogram of } \mathrm{BW})\end{array}$ & 0.06 & 0.07 & 0.03 & 0.05 & 0.01 & 0.27 & 1.00 \\
\hline
\end{tabular}

${ }^{1} \mathrm{AUC}=$ area under the curve (discounting baseline concentration).

${ }^{2}$ Calculated according to Christoffersen et al. (2009). 
Baldwin et al., 2004). During the transition to a mature ruminant state, where supply of lactose as an energy source is reduced, adaptations in glucose metabolism (Baldwin et al., 2004) may prevent possible insulin sensitivity before the transition.

\section{Mammary Gland}

The average pixels in the mammary fat pad area was not influenced by the TS concentrations of the liquid feed provided during the preweaning period (Table 5). We noted, however, an increase in the average pixels as heifers developed $(P=0.01$, Figure 1c). This suggests that the increase of mammary gland fat pad occurred according to age without an effect of the preweaning nutrition on the postweaning development of the mammary gland. According to Capuco et al. (1995), as BW increases, the fat pad of the mammary gland also increases. Meyer et al. (2006) found no differences in parenchyma composition among animals submitted to restricted or elevated nutritional plans, showing that the development of parenchyma seems to be more related to chronological age than to nutrition. The mammary gland fat pad content is, however, sensitive to nutritional changes. A greater nutrient intake leads to greater accumulation of lipids in the adipocytes, resulting in hypertrophy (Meyer et al., 2006). In the present study, all animals were evaluated at the same age and we found no difference in BW and ADG in the studied periods, which may justify the absence of differences in mammary fat pad among groups. These results, combined with those observed by Azevedo et al. (2016b), who reported no change in the percentage of fat in the body composition of male dairy calves receiving liquid feed with TS concentrations similar to that used in the present study, support the hypothesis of a similar effect on body composition and mammary gland of heifers.

The average pixels among the evaluated quarters differed $(P=0.01)$. Greater pixel values were observed in the rear mammary glands $(108,489 \pm 775$ pixels $)$ than the front glands $(105,048 \pm 770$ pixels $)$.

\section{CONCLUSIONS}

Increasing TS in whole milk by adding milk replacer powder up to $20.4 \%$ during the preweaning period did not affect intake, postweaning performance, or age at puberty of dairy heifers, as well as it did not alter glucose metabolism nor the mammary gland fat pad. Conversely, the increase in liquid feed TS concentration during the preweaning period linearly increased the measurements of hip width and heart girth up to 150 and $240 \mathrm{~d}$ of age, respectively. 


\section{ACKNOWLEDGMENTS}

The authors thank Coordenação de Aperfeiçoamento de Pessoal de Nível Superior (CAPES, Brasília, Brazil), Fundação de Amparo à Pesquisa do Estado de Minas Gerais (FAPEMIG, Minas Gerais, Brazil), Conselho Nacional de Desenvolvimento Científico e Tecnológico (CNPq, Minas Gerais, Brazil), and Embrapa Dairy Cattle (Minas Gerais, Brazil) for financially supporting this research.

\section{REFERENCES}

Albino, R. L., S. E. F. Guimarães, K. M. Daniels, M. M. S. Fontes, A. F. Machado, G. B. Dos Santos, and M. I. Marcondes. 2017. Technical note: Mammary gland ultrasonography to evaluate mammary parenchymal composition in prepubertal heifers. J. Dairy Sci. 100:1588-1591.

Albino, R. L., M. I. Marcondes, R. M. Akers, E. Detmann, B. C. Carvalho, and T. E. Silva. 2015. Mammary gland development of dairy heifers fed diets containing increasing levels of metabolisable protein: Metabolisable energy. J. Dairy Res. 82:113-120.

AOAC International. 1995. Official Methods of Analysis of AOAC International. 16th ed. AOAC International, Arlington, VA.

Azevedo, R. A., F. S. Machado, M. M. Campos, P. M. Furini, S. R. A. Rufino, L. G. R. Pereira, T. R. Tomich, and S. G. Coelho. 2016a. The effects of increasing amounts of milk replacer powder added to whole milk on feed intake and performance in dairy heifers. J. Dairy Sci. 99:8018-8027.

Azevedo, R. A., F. S. Machado, M. M. Campos, D. R. G. Lopes, S. F. Costa, H. C. Mantovani, F. C. F. Lopes, M. I. Marcondes, L. G. R. Pereira, T. R. Tomich, and S. G. Coelho. 2016b. The effects of increasing amounts of milk replacer powder added to whole milk on passage rate, nutrient digestibility, ruminal development, and body composition in dairy calves. J. Dairy Sci. 99:8746-8758.

Bach, A., L. Domingo, C. Montoro, and M. Terré. 2013. Short communication: Insulin responsiveness is affected by the level of milk replacer offered to young calves. J. Dairy Sci. 96:4634-4637.

Baldwin, R. L., VI, K. R. McLeod, J. L. Klotz, and R. N. Heitmann. 2004. Rumen development, intestinal growth and hepatic metabolism in the pre- and postweaning ruminant. J. Dairy Sci. 87(Suppl.):E55-E65.

Ballou, M. A., D. L. Hanson, C. J. Cobb, B. S. Obeidat, M. D. Sellers, A. R. Pepper-Yowell, J. A. Carrol, T. J. Earleywine, and S. D. Lawhon. 2015. Plane of nutrition influences the performance, innate leukocyte responses, and resistance to an oral Salmonella enterica serotype Typhimurium challenge in Jersey calves. J. Dairy Sci. 98:1972-1982.

Brown, E. G., M. J. Vandehaar, K. M. Daniels, J. S. Liesman, L. T. Chapin, J. W. Forrest, R. M. Akers, R. E. Pearson, and M. S. Nielsen. 2005. Effect of increasing energy and protein intake on mammary development in heifer calves. J. Dairy Sci. 88:595-603.

Capuco, A. V., J. J. Smith, D. R. Waldo, and C. E. Rexroad. 1995. Influence of prepubertal dietary regimen on mammary growth of Holstein heifers. J. Dairy Sci. 78:2709-2725.

Chizzotti, M. L., F. S. Machado, E. E. L. Valente, L. G. R. Pereira, M. M. Campos, T. R. Tomich, S. G. Coelho, and M. N. Ribas. 2015. Technical note: Validation of a system for monitoring individual feeding behavior and individual feed intake in dairy cattle. J. Dairy Sci. 98:3438-3442.

Christoffersen, B., U. Ribel, K. Raun, V. Golozoubova, and G. Pacini. 2009. Evaluation of different methods for assessment of insulin sensitivity in Gottingen minipigs: Introduction of a new, simpler method. Am. J. Physiol. Regul. Integr. Comp. Physiol. 297:R1195-R1201.

Davis Rincker, L. E., M. J. VandeHaar, C. A. Wolf, J. S. Liesman, L. T. Chapin, and M. S. Weber Nielsen. 2011. Effect of intensified feeding of heifer calves on growth, pubertal age, calving age, milk yield, and economics. J. Dairy Sci. 94:3554-3567.

Eckert, E., H. E. Brown, K. E. Leslie, T. J. DeVries, and A. Steele. 2015. Weaning age affects growth, feed intake, gastrointestinal development, and behavior in Holstein calves fed an elevated plane of nutrition during the preweaning stage. J. Dairy Sci. 98:6315-6326.

Edmonson, A. J., I. J. Lean, L. D. Weaver, T. Farver, and G. Webster. 1989. A body condition scoring chart for Holstein dairy cows. J. Dairy Sci. 72:68-78.

Esselburn, K. M., T. M. Hill, H. G. Bateman, F. L. Fluharty, S. J. Moeller, K. M. O'diam, and K. M. Daniels. 2015. Examination of weekly mammary parenchymal area by ultrasound, mammary mass, and composition in Holstein heifers reared on 1 of 3 diets from birth to 2 months of age. J. Dairy Sci. 98:5280-5293.

Facó, O., R. N. B. Lôbo, R. M. Filho, and F. A. M. Lima. 2005. Idade ao Primeiro Parto e Intervalo de Partos de Cinco Grupos Genéticos Holandês x Gir no Brasil. Rev. Bras. Zootec. 34:1920-1926.

Ferreira, T. and W. S. Rasband. 2011. ImageJ User Guide - IJ 146. Accessed Aug. 25, 2017. https://imagej.nih.gov/ij/.

Geiger, A. J., C. L. M. Parsons, and R. M. Akers. 2016b. Feeding a higher plane of nutrition and providing exogenous estrogen increases mammary gland development in Holstein heifer calves. J. Dairy Sci. 99:7642-7653.

Geiger, A. J., C. L. M. Parsons, R. E. James, and R. M. Akers. 2016a. Growth, intake, and health of Holstein heifer calves fed an enhanced pre-weaning diet with or without exogenous estrogen. J. Dairy Sci. 99:3995-4004.

Gelsinger, S. L., A. J. Heinrichs, and C. M. Jones. 2016. A metaanalysis of the effects of preweaned calf nutrition and growth on first-lactation performance. J. Dairy Sci. 99:6206-6214.

Grütter, R., and J. W. Blum. 1991. Original article Insulin and glucose in neonatal calves after peroral division of nutrition. Reprod. Nutr. Dev. 31:389-397.

Guindon, N. E., N. T. Antaya, R. G. Cabral, N. L. Whitehouse, T. J. Earleywine, and P. S. Erickson. 2015. Effects of human visitation on calf growth and performance of calves fed different milk replacer feeding levels. J. Dairy Sci. 98:8952-8961.

Jensen, M. B., L. R. Duve, and D. M. Weary. 2015. Pair housing and enhanced milk allowance increase play behavior and improve performance in dairy calves. J. Dairy Sci. 98:2568-2575.

Khan, M. A., H. J. Lee, W. S. Lee, H. S. Kim, K. S. Ki, T. Y. Hur, G. H. Suh, S. J. Kang, and Y. J. Choi. 2007. Structural growth, rumen development, and metabolic and immune responses of Holstein male calves fed milk through step-down and conventional methods. J. Dairy Sci. 90:3376-3387.

Kiezebrink, D. J., A. M. Edwards, A. T. C. Wright, J. P. Cant, and V. R. Osborne. 2015. Effect of enhanced whole-milk feeding in calves on subsequent first-lactation performance. J. Dairy Sci. 98:349-356.

MacPherson, J. A. R., H. Berends, L. N. Leal, J. P. Cant, J. MartinTereso, and M. A. Steele. 2016. Effect of plane of milk replacer intake and age on glucose and insulin kinetics and abomasal emptying in female Holstein Friesian dairy calves fed twice daily. J. Dairy Sci. 99:8007-8017.

Marett, L. C., M. J. Auldist, P. J. Moate, W. J. Wales, K. L. Macmillan, F. R. Dunshea, and B. J. Leury. 2015. Response of plasma glucose, insulin, and nonesterified fatty acids to intravenous glucose tolerance tests in dairy cows during a 670-day lactation. J. Dairy Sci. 98:179-189.

Meyer, M. J., A. V. Capuco, D. A. Ross, L. M. Lintault, and M. E. Van Amburgh. 2006. Developmental and nutritional regulation of the pre-pubertal heifer mammary gland: parenchyma and fat pad mass and composition. J. Dairy Sci. 89:4289-4297.

Miller-Cushon, E. K., R. Bergeron, K. E. Leslie, and T. J. DeVries. 2013. Effect of milk feeding level on development of feeding behavior in dairy calves. J. Dairy Sci. 96:551-564.

Nishimura, M., T. Yoshida, S. El-Khodery, M. Miyoshi, H. Furuokam, J. Yasuda, and K. Miyahara. 2011. Ultrasound imaging of mammary glands in dairy heifers at different stages of growth. J. Vet. Med. Sci. 73:19-24. 
Obeidat, B. S., C. J. Cobb, M. D. Sellers, A. R. Pepper-Yowell, T. J. Earleywine, and M. A. Ballou. 2013. Plane of nutrition during the preweaning period but not the grower phase influences the neutrophil activity of Holstein calves. J. Dairy Sci. 96:7155-7166.

Omidi-Mirzaei, H., M. Khorvash, G. R. Ghorbani, B. Moshiri, M. Mirzaei, A. Pezeshki, and M. H. Graffari. 2015. Effects of the step-up/step-down and step-down milk feeding procedures on the performance, structural growth, and blood metabolites of Holstein dairy calves. J. Dairy Sci. 98:7975-7981.

Overvest, M. A., R. Bergeron, D. B. Haley, and T. J. DeVries. 2016. Effect of feed type and method of presentation on feeding behavior, intake, and growth of dairy calves fed a high level of milk. J. Dairy Sci. 99:317-327.

Pires, J. A. A., A. H. Souza, and R. R. Grummer. 2007. Induction of hyperlipidemia by intravenous infusion of tallow emulsion causes insulin resistance in Holstein cows. J. Dairy Sci. 90:2735-2744.

Raeth-Knight, M., H. Chester-Jones, S. Hayes, J. Linn, R. Larson, and D. Ziegler. 2009. Impact of conventional or intensive milk replacer programs on Holstein heifer performance through six months of age and during first lactation. J. Dairy Sci. 92:799-809.

Schillo, K. K., J. B. Hall, and S. M. Hileman. 1992. Effects of nutrition and season on the onset of puberty in the beef heifer. J. Anim. Sci. 70:3994-4005.

Shamay, A., D. Werner, U. Moallem, H. Barash, and I. Bruckental. 2005. Effect of nursing management and skeletal size at weaning on puberty, skeletal growth rate, and milk production during first lactation of dairy heifers. J. Dairy Sci. 88:1460-1469.
Silper, B. F., A. M. Q. Lana, A. U. Carvalho, C. S. Ferreira, A. P. S Franzoni, J. A. M. Lima, H. M. Saturnino, R. B. Reis, and S. G. Coelho. 2014. Effects of milk re-placer feeding strategies on performance, ruminal development, and metabolism of dairy calves. J. Dairy Sci. 97:1016-1025.

Sumner, J. M., F. Valdez, and J. P. McNamara. 2007. Effects of chromium propionate on response to an intravenous glucose tolerance test in growing Holstein heifers. J. Dairy Sci. 90:3467-3474.

Sweeney, B. C., J. Rushen, D. M. Weary, and A. M. De Passillé 2010. Duration of weaning, starter intake, and weight gain of dairy calves fed large amounts of milk. J. Dairy Sci. 93:148-152.

Terré, M., C. Tejero, and A. Bach. 2009. Long-term effects on heifer performance of an enhanced-growth feeding programme applied during the preweaning period. J. Dairy Res. 76:331-339.

Van Soest, P. J., J. B. Robertson, and A. Lewis. 1991. Methods for dietary fiber, neutral detergent fiber, and non starch polysaccharides in relation to animal nutrition. J. Dairy Sci. 74:3583-3597.

Weller, M. M. D. C. A., R. L. Albino, M. I. Marcondes, W. Silva, K. M. Daniels, M. M. Campos, M. S. Duarte, M. L. Mescouto, F. F. Silva, and S. E. F. Guimaraes. 2016. Effects of nutrient intake level of same diet on mammary parenchyma growth and gene expression in crossbreed (Holstein x Gyr) prepubertal heifers. J. Dairy Sci. 99:9962-9973

Yunta, C., M. Terré, and A. Bach. 2015. Short- and medium-term changes in performance and metabolism of dairy calves offered different amounts of milk replacers. Livest. Sci. 181:249-255. 